Мирко Обрадовић

Универзитет у Београду

Филозофски факултет

Одељење за историју

mdobrado@f.bg.ac.rs
Оригиналан научни рад

примљено: 21. мај 2014

прихваћено: 1. октобар 2014

\title{
ПРИЛОЗИ ПРОУЧАВАњУ \\ НЕЛЕИДСКЕ АНТРОПОНИМИЈЕ III: \\ ХЕРОЈСКО ИМЕ ПЕЈСИСТРАТ КАО ЛИЧНО ИМЕ КОД ХЕЛЕНА
}

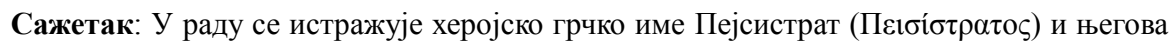
дистрибуција као личног имена у хеленском свету. Иако је по образовању и значењу реч о добром ратничком имену, разлоге за давање херојског имена Пејсистрат смртним људима треба тражити, пре свега, у чињеници да је оно нелеидско (име једног од Несторових синова) и хомерско (добро потврђено у хомерском епу Одисеја). Као такво било је прихватљиво нарочито Јоњанима, одакле се може тумачити и популарност имена најпре у Атици, али и у другим јонским крајевима, у малоазијској Јонији и на острвима у Егејском мору. Како је овде, међутим, реч о хероју истакнутом у млађем хомерском епу, име Пејсистрат је могло бити подједнако блиско и свим другим Грцима као панхеленско лично име, па не треба да чуди, на пример, његова популарност као антропонима на острву Родосу, као и у другим градовима малоазијске Дориде (Кос, Книд, Калимнос), одакле долази највећи број потврда у изворима у хеленистичком периоду. С друге стране, у раду се разматрају и разлози зашто је име Пејсистрат као лично име временом постало непожељно у самој Атини. Пошто је реч о имену које је носио славни атински тиранин Пејсистрат и чланови његове породице, име је у демократској Атини V и IV века пре н. е., али и у каснијој традицији, доживљавано као тиранско и омражено, те зато није могло бити сматрано добрим знамењем.

Кључне речи: Пејсистрат, грчка антропонимија, Нелеиди, етимологија, грчка епика, мит, историја, политика, културне вредности.

У наставку наших проучавања нелеидских херојских имена и могућих разлога за давање имена из херојског репертоара смртним људима, након имена Антилох и Трасимед, ${ }^{1}$ на ред да се истражи дошло је и херојско име Пејсистрат.

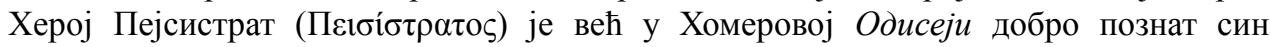

\footnotetext{
${ }^{1}$ Упор. М. Обрадовић, Херојско име Антилох као лично име код Хелена, Истраживања 23, Нови Сад 2012, 95-109; Исти, Прилози проучавању нелеидске антропонимије II: херојско име Трасимед као лично име код Хелена, Истраживања 24, Нови Сад 2013, 23-39.
} 
великог Нестора из Пила. Овај Несторид је у другом славном хомерском епу представљен управо као онај херој који први сачекује Одисејевог сина Телемаха на песковитој обали Пила. ${ }^{2}$ Пејсистрат је очигледно најмлађи од преосталих Несторових синова и једини који у време Телемаховог доласка још није био ожењен. Као најмлађем, њему и пристаје да у име домаћина први пожели добродошлицу странцима и путницима. ${ }^{3}$ Његов углед и статус међу Несторовим синовима

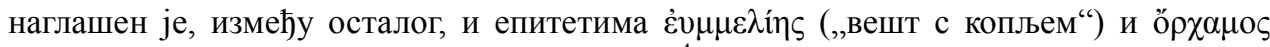
$\dot{\alpha} v \delta \rho \tilde{\omega} v\left(\right.$ „вођа људи“, заправо „вођа јунака“"). ${ }^{4}$ Касније је очекивано био и Телемахов пратилац на путу у Спарту код краља Менелаја где је Одисејев син, по налогу богиње Атине, истраживао судбину свог оца, као и на његовом повратку преко Пелопонеза. ${ }^{5}$ Син овог хероја Пејсистрата, такође у традицији познат као Пејсистрат, заједно је са осталим Нелеидима у време тзв. повратка Хераклида на Пелопонез нашао уточиште у Атици и сматран је родоначелником породице најславнијег атинског тиранина Пејсистрата. ${ }^{6}$ Наведене чињенице су у битној мери

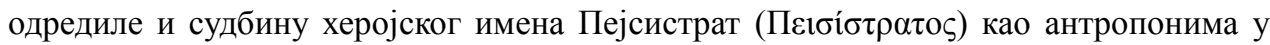
хеленском свету у антици. Име се зато у каснијим епохама, а нарочито у периоду од $\mathrm{V}$ века пре н. е., и могло јавити као херојско, епско име, али и као историјско. Наиме, као лично име могло је бити давано деци са погледом на хероја Пејсистрата, угледног и вољеног Несторовог сина из Одисеје, али исто тако и са свешћу да је историјско име, популарно због славе атинског државника Пејсистрата као историјске личности.

С друге стране, лично име Пејсистрат је по свом образовању, пре свега, добро ратничко име: први део имена Пєıб- изведен је извесно од старогрчког $\pi \varepsilon i ́ \vartheta \omega$,

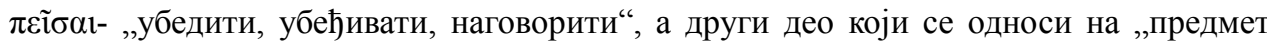

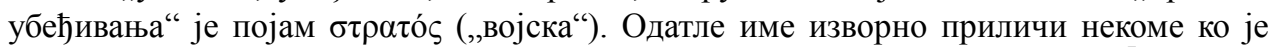
војсковођа, заповедник и командант и који зна како да поступа са војском. ${ }^{7}$ Тај неко је заправо сам отац Пејсистратов, велики херој Нестор. Тако Пејсистрат, Несторов син, извесно носи „речито“ име које треба да укаже на добре особине његовог оца, који је и у својој крепкој старости, а нарочито као младић, био неоспорно вешт у командовању и руковођењу војском. Ратничка имена овог типа добро су позната већ

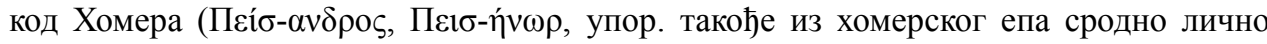

\footnotetext{
${ }^{2}$ Od. III 36.

${ }^{3}$ Упор. A. Heubeck, S. West, J. B. Hainsworth, A Commentary on Homer's Odyssey. Vol. 1: Introduction and Books 1-8, Oxford 1988, 162.

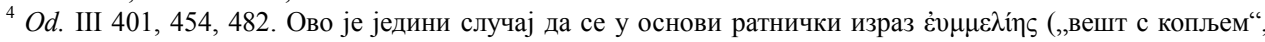
односно „копљометан“) јавља као епитет у Одисеји (сви остали примери потичу из Илијаде), а хомерски

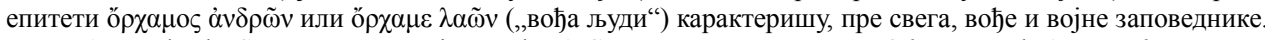
Упор. А. Heubeck, S. West, J. B. Hainsworth, A Commentary on Homer's Odyssey. Vol. 1: Introduction and

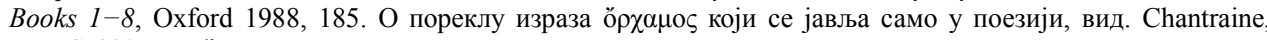
$D E L G, 830$, s. v. ö $\rho \chi \alpha \mu$ os.

${ }^{5}$ Od. IV; XV 1-238.

${ }^{6}$ За разлоге да се и унук Несторов, баш као и син, назове у познијој традицији (упор. нпр. Рaus. II 18, 8) Пејсистратом, вид. Н. Mühlestein, Nestors Enkel Peisistratos, Zeitschrift für Papyrologie und Epigraphik 87, Bonn 1991, 78 .

7 H. von Kamptz, Homerische Personennamen: sprachwissenschaftliche und historische Klassifikation, Göttingen 1982, 65, 215.
} 
име Ev̉- $\varepsilon \varepsilon \dot{\vartheta} \eta$ ), а јављају се као антропоними и у различитим епохама старе грчке историје. $^{8}$ За нашу тему свакако није без значаја што се и један од Несторових

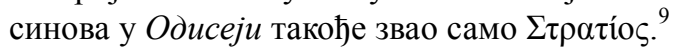

Међу атинским аристократским породицама архајске епохе које су изводиле своје порекло од херојских Нелеида из Пила свакако значајно место заузима и

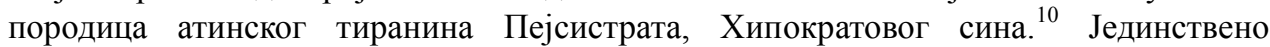
сведочанство да је управо Пејсистрат, атински тиранин, своје име дуговао Пејсистрату, Несторовом сину, из Пила, оставио нам је велики грчки историчар и прозни писац Херодот у својој Историји. Он изричито наводи да је Хипократ, отац потоњег тиранина Пејсистрата, сину дао име са погледом на хероја Пејсистрата, Несторовог сина. Говорећи, наиме, о судбини Пејсистратида након њиховог збацивања с власти у Атини 510. године пре н. е., Херодот, између осталог, каже и да су „они [Пејсистратиди] били пореклом из Пила и потомци Нелеја, исто као и Кодро и Мелант, који су се раније доселили у Атину и тамо од странаца постали краљеви. Хипократ је, наиме, то и имао на уму када је, за успомену на Несторова сина Пејсистрата, и дао своме сину ово име“. ${ }^{11}$ Нужно се намеће питање да ли се Херодотовом казивању може у потпуности поклонити поверење; и то не само у оном делу који се наводно односи на порекло Пејсистратида од Нелеида, јер су захтеви тог типа готово опште место код аристократских породица у хеленском свету, па тако и у самој Атини (како то, на пример, јасно показују генеалогије породица Филаида или Алкмеонида), већ и у оном делу који се односи на само именовање и тиче се у основи питања да ли је већ крајем VII века пре н. е. атински племић Хипократ могао дати име сину баш са погледом на хероја из Пила. ${ }^{12}$ Често се у модерној науци о Пејсистратидима, без сигурне потпоре у изворима, говори као о неугледној породици, која је вртоглави успон постигла само захваљујући личним, пре свега војничким, а затим и државничким квалитетима самог Пејсистрата. Истакавши се најпре у рату са атинским архинепријатељима Мегаранима, Пејсистрат се активно укључио у политички живот града, супротстављајући се традиционално моћним атинским еупатридским породицама и, својом довитљивошћу, талентом за политику и уз потпору сиромашнијих слојева

\footnotetext{
${ }^{8}$ Упор. F. Bechtel, Die historischen Personennamen des Griechischen bis zur Keiserzeit, Halle 1917, 368-369.

${ }^{9}$ Od. III 413, 439.

${ }^{10}$ О тиранину Пејсистрату, његовој владавини, као и о владавини његових синова у Атини, литература је огромна. На овом месту издвајамо само она дела која, чини се, на најбољи начин сумирају резултате науке који се тичу карактера тираниде Пејсистрата и Пејсистратида, као и бројних проблема у вези са хронологијом и просопографским подацима: F. Schachermeyr, $R E$ 19, 1938, 150-155, s. v. Peisistratiden; F. Schachermeyr, RE 19, 1938, 156-191, s. v. Peisistratos (3); A. Andrews, The Greek Tyrants, London 1956, 100-115; H. Berve, Die Tyrannis bei den Griechen, I-II, München 1967, 47-77; 543-563; J. K. Davies, Athenian Propertied Families 600-300 B. C., Oxford 1971, 444-455; A. Andrews, The Tyranny of Pisistratus, The Cambridge Ancient History III $^{2}$ 3, Cambridge 1982, 392-416.

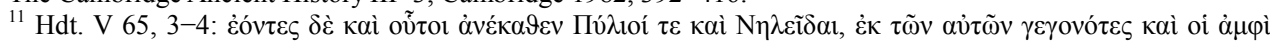

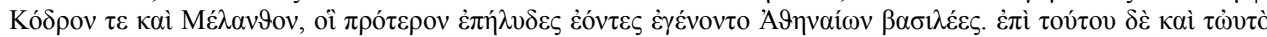

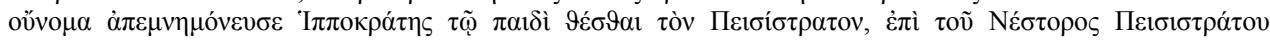

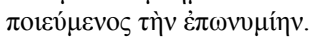

${ }_{12}$ Пејсистрат је рођен између, отприлике, 605. и 600. године пре н. е. Упор. F. Schachermeyr, RE 19, 1938, 150, s. v. Peisistratiden; J. K. Davies, Athenian Propertied Families 600-300 B. C., Oxford 1971, 445.
} 
становништва Атике (тзв. „брђана“, односно diakrioi или hyperakrioi) докопао се тиранске власти. С тим у вези, и „нелеидска“ се компонента породичне традиције везује обично за самог Пејсистрата, па се тако наводи да је она заправо и „настала“ тек као резултат тиранинове пропаганде. ${ }^{13}$ Као да се, притом, заборавља да Пејсистрат, Хипократов син, није и први историјски Пејсистрат забележен у изворима и, уопште, у атинској традицији. Извори поуздано бележе извесног Пејсистрата као атинског архонта за 669/8. годину пре н. е. ${ }^{14}$ Да овај Пејсистрат није фикција, односно резултат претпостављене накнадне интервенције у листи атинских архоната, могао би да покаже и један рани атински натпис из архајске епохе на комаду керамике на коме је урезано лично име Пејсистрат, а који је госпођа Лилијан Џефри (L. Jeferry), највећи стручњак за ране грчке алфабете, са великом сигурношћу датовала у VII век пре н. е. ${ }^{15}$ Не треба искључити могућност да се забележено лично име Пејсистрат управо односи на поменутог атинског архонта из прве половине VII века, ${ }^{16}$ а овај би најпре могао бити предак и рођак тиранина Пејсистрата.

Не улазећи на овом месту детаљније у бројне историјске проблеме који постоје у вези са Пејсистратовом тиранијом, јер би на тај начин изашли из оквира теме, мислимо да не може бити речи о случајности када је у питању само тираниново име. Оно је такође, уосталом као и друга карактеристична имена преузета из херојског репертоара, могло бити наслеђивано кроз генерације у једној породици. Тако се сасвим природно и очекивано десило да се унук великог

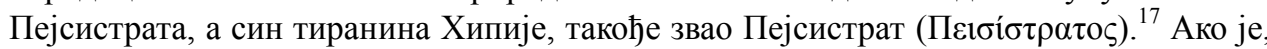
дакле, најстарији поменути Пејсистрат, атински архонт за 669/8. годину пре н. е., такође, како смо претпоставили, био члан исте породице, забележена су у периоду од, отприлике, век и по, најмање три Пејсистрата из истог круга и у оквиру једне исте породице. Да је име Пејсистрат, као и атинска породица у којој се име јавља, рано могло бити доведено у везу са Нелеидима из Пила, поред наведеног Херодотовог податка, сведочи и њихова веза са племићком породицом Алкмеонида, који су исто тако изводили порекло од Нелеида, у линији по Несторовом сину Трасимеду. Пејсистратиди су, очигледно не случајно, у изворима навођени и као рођаци (syngeneis) Алкмеонида. ${ }^{18}$ Појам syngeneia („,сродство“) у хеленском свету у старини могао је у пракси да носи широк спектар различитих значења: да укаже на

\footnotetext{
${ }^{13}$ Последњи, колико нам је познато, ову тезу заступа В. M. Lavelle, Fame, Money, and Power: The Rise of Peisistratos and "Democratic" Tyranny at Athens, Ann Arbor 2005, 18 и д.

${ }^{14}$ Paus. II 24, 7. Упор. R. Develin, Athenian Officials 684-321 B. C., Cambridge 1989, 28 (архонт у четвртој години 27. Олимпијаде $=669 / 8$. год. пре н. е.).

${ }^{15}$ Jeffery, $L S A G, 70,76$ (Cat. no. 9e), Pl. 2.

${ }^{16}$ Вид. Jeffery, $L S A G, 70:, \ldots$ if it is to be connected with any known historical figure, may be ascribed to that Peisistratos who was archon in 669/8“. Упор. $L G P N$ II, s. v. Peisistratos (1)-(2).

${ }^{17}$ Овај Пејсистрат је највероватније био атински архонт епоним за 522/521. годину пре н. е. (трећа година 64. Олимпијаде). О свом архонтату оставио је драгоцено сведочанство у виду посвете и натписа на жртвенику посвећеном Аполону Питијском, $I G \mathrm{I}^{3} 948$ = Meiggs/Lewis, GHI 11, а што све потврђује и историчар Тукидид (Thuc. VI 54, 6-7). Упор. R. Develin, Athenian Officials 684-321 B. C., Cambridge 1989, 47; J. K. Davies, Athenian Propertied Families 600-300 B. C., Oxford 1971, 450-451; LGPN II, s. v. Peisistratos (4).

${ }^{18}$ Упор. R. Thomas, Oral Tradition and Written Record in Classical Athens, Cambridge 1989, 147-48.
} 
директно крвно сродство, као и на сродство успостављено путем брачних веза, ${ }^{19}$ али такође и да се односи на фиктивно сродство, употребљено у митском и генеалошком контексту да се њиме нагласи сродство породица, родова, градова, па и читавих народа преко хероја и заједничких херојских предака. ${ }^{20}$ То што су Пејсистратови „рођаци“ Алкмеониди одиграли пресудну улогу у свргавању с власти Пејсистратида у Атини не мења праву суштину ствари и не сведочи о стварној природи њихових међусобних „крвних“ веза. Међутим, традиција о заједничком нелеидском пореклу у две од три водеће атинске породице у VI веку пре н. е. (трећа моћна породица Филаиди изводила је своје порекло од хероја Великог или саламинског Ајанта, дакле од херојских Ајакида) сведочи несумњиво о престижу Нелеида у Атини архајске епохе. Можемо се с правом запитати који стварни разлози леже у позадини свега тога и који су све фактори допринели да се свест о Нелеидима на тај начин учврсти међу ондашњим Атињанима. Спекулисало се, како у антици тако и међу модерним истраживачима, о могућим утицајима који су долазили с друге стране Егејског мора, пре свега од малоазијских Јоњана. Веровало се да се у тој ствари атинско племство заправо угледало на оно по градовима малоазијске Јоније, где је најпре, делом сигурно под утицајем епова и усмене традиције, прихваћена као историјска чињеница далека веза са Пилом и неоспорна улога Нелеида у сеоби Јоњана у Малу Азију. Те митско-историјске везе су временом, за сопствене потребе, усвојили атински аристократи. Основни мит о пореклу историјских Јоњана повезује прогнане Нелеиде из Пила и првобитне Јоњане из Ахаје, који су се сви најпре склонили у Атику, а одатле заједно населили малоазијску Јонију. ${ }^{21}$ Управо из времена с краја VII или почетка VI века пре н. е. налазимо и у самој Атини најраније потврде ове традиције код песника и законодавца Солона, који Атику први назива и „најстаријом јонском земљом“.22

Доста тога у вези са настанком ове традиције није данас јасно, али сигурно је да лична имена, што модерни истраживачи често занемарују, могу представљати важан извор у оцени карактера и порекла ових веза. Остављајући сада по страни малоазијску Јонију, неоспорно је да су Нелеиди баш у Атини уживали нарочит престиж међу херојским родовима и да су аристократске породице које су се бориле

\footnotetext{
${ }^{19}$ Пејсистрат је у одређеном политичком тренутку (отприлике 557. године пре н. е.) из династичких и савезничких разлога накратко био ожењен Агаристом, ћерком Мегакла, вође алкмеонидског клана и странке тзв. „примораца“ paralioi (Hdt. I 61, 1-2; Arist. Ath. Pol. 15, 1), али овај брак „из рачуна“ није, правничким речником речено, конзумиран и растурен је онога тренутка када за њега више није постојало политичких разлога.

${ }^{20}$ Колико је у пракси појам „сродства“ био „растегљив“ и могао да игра важну улогу у дипломатији и међудржавним односима, нарочито у хеленистичком периоду, показују бројне студије на ту тему публиковане последњих деценија: О. Curty, Les parentés légendaires entre cités grecques. Catalogue raisonné

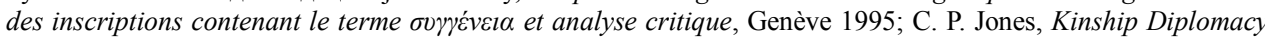
in the Ancient World, Cambridge, Mass. 1999; S. Lücke, Syngeneia: Epigraphisch-historische Studien zu einem Phänomen der antiken griechischen Diplomatie (Frankfurter althistorische Beiträge, Bd. 5), Frankfurt am Mein 2000.

21 Упор. нпр. М. В. Sakellariou, La migration grecque en Ionie, Athènes 1958, passim; F. Prinz, Gründungsmythen und Sagenchronologie (Zetemata 72), München 1979, 314-376.

${ }^{22}$ Solon F 4a = Arist. Ath. Pol. 5, 2. Упор. F. Prinz, Gründungsmythen und Sagenchronologie (Zetemata 72), München 1979, 374: „Als Zeitpunkt dieser Ionisierung Athens muß das 7. Jhdt. angesetzt werden, und der Anspruch der Athener auf Ionertum ist nur an dessen Ende durch Solon zum ersten Male ganz eindeutig belegt".
} 
за примат сматрале да је политички профитабилно истаћи везу са Нелејевим херојским потомством. Мислимо да је већ то, само по себи, довољно да би се јасније разумела политичка ситуација и друштвена клима у којој се херојска нелеидска имена јављају као антропоними.

У Атини се, међутим, име Пејсистрат, ако оставимо по страни породицу најславнијег атинског тиранина, изузетно ретко јавља као антропоним. То се може најбоље објаснити управо претпоставком да је ово име код атинских грађана доживљавано као тиранско, односно да је Несторов Пејсистрат временом „устукнуо“ пред Пејсистратом тиранином у колективном сећању народа. Историјска свест однела је тако победу над епском свешћу, а на име Пејсистрат могло се гледати као на лоше знамење и оно је нарочито у демократској Атини сматрано непожељним. Иако традиција углавном позитивно суди о тиранину Пејсистрату, о владавини његових синова, а нарочито најстаријег Хипије, мишљења су неподељена и изузетно лоша. Хипија није само, за разлику од оца Пејсистрата, владао крајње сурово (нарочито у годинама после атентата на брата Хипарха), ${ }^{23}$ већ је уз помоћ страних сила и великих супарника Атине, најпре Спарте, али затим и омрзнуте варварске Персије (у време Маратонске битке), покушао да се врати на власт. Зато у демократском атинском друштву које је, с правом или не, на овом месту то и није толико битно, тираноубице Хармодија и Аристогејтона славило као највеће националне хероје и спаситеље, ${ }^{24}$ више није било места за тиране, чак ни за „старог“ Пејсистрата, који би можда, у неким другим историјском околностима, код народа вероватно „прошао“ далеко боље. Овако је и само име Пејсистрат у демократској Атини V и IV века пре н. е., али и у каснијој традицији, постало омражено и доживљавано је као тиранско. Због свега тога, од атинских Пејсистрата из наредних векова, у сачуваним су изворима забележена само два грађанина са овим личним именом у IV веку пре н. е., и то оба у деми Кефисији: један Пејсистрат, отац

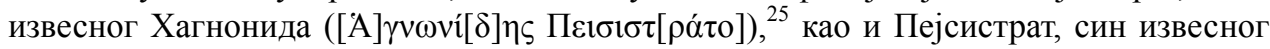

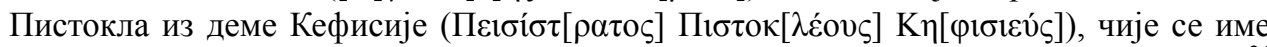
са сигурношћу да допунити на надгробном споменику из IV века пре н. е. ${ }^{26}$ Занимљиво је, међутим, да је у Атини забележен и женски еквивалент овога, по својој природи и значењу, мушког личног имена, па се на натписима из истог периода (IV век пре н. е.) могу прочитати и имена две атинске Пејсистрате

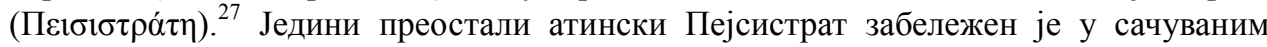

\footnotetext{
23 Одјеке ове негативне традиције у демократској Атини класичне епохе налазимо већ код Тукидида (Thuc. VI 54-60,1), а посебно у Платоново време, у првој половини IV века пре н. е. Упор. нпр. [Plat.] Hipparch. 229b.

24 Указиване су им херојске почасти (упор. Arist. Ath. Pol. 58, 1), у њихову част су испеване здравице (упор. Athen. XV 50, 695a-b), а њихови потомци су уживали привилегије у граду $\left(I G \mathrm{I}^{3} 131\right)$. Славне статуе тираноубица Хармодија и Аристогејтона, које је својевремено персијски цар Ксеркс однео из Атине као ратни плен, видео је на почасном месту у Атини још у II веку н. е. путописац Паусанија (Paus. I $8,5)$.

${ }_{25}^{25} S E G 18,36$ А, редови 249-50 (датовање отприлике између 330. и 310 . год. пре н. е.). Упор. $L G P N$ II, s. v. Peisistratos (5).

${ }^{26} I G \mathrm{II}^{2} 6436+S E G 13,98$. Упор. LGPN II, s. v. Peisistratos (6).

${ }^{27} I G \mathrm{II}^{2} 5757$, надгробни споменик атинског грађанина Кефисофонта из деме Афидне, чија се жена звала

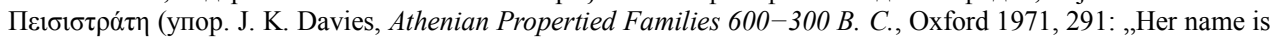


изворима тек много векова касније, почетком III века н. е. Овај Аурелије Пејсистрат,

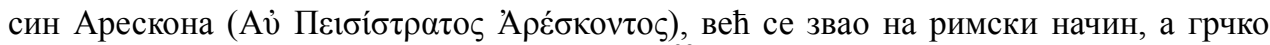
име Пејсистрат му је наведено као когномен. ${ }^{28}$

С друге стране, оно што је у Атини очигледно било мана или представљало препреку, то је у другим деловима Хеладе могло изгледати као предност приликом давања личних имена новорођеној деци. Грађанима грчких градова који нису осетили „благодети“ Пејсистратове тираниде име се могло учинити као добро ратничко и херојско, али такође и као славно историјско име. Управо чињеница да је Пејсистрат и име хероја из популарног хомерског епа, могла је бити само додатни разлог да се јаве оваква именовања. Далеко највећи број историјских Пејсистрата потврђен је на острву Родосу. У периоду између, отприлике, IV и I века пре н. е. забележено је чак четрдесетак „рођанских“ Пејсистрата ${ }^{29}$ у различитим изворима, пре свега у богатом епиграфском материјалу са Родоса из хеленистичке епохе, а затим и као име магистрата на новцу, ${ }^{30}$ или опет као име епонимних магистрата на дршкама амфора произведених на острву. ${ }^{31}$ За могуће историјске разлоге зашто су имена Несторових синова, па тако и име Пејсистрат, често у употреби као лична имена код Рођана хеленистичке епохе, већ је било довољно речи у претходном броју овог истог часописа у вези са херојским именом Трасимед. ${ }^{32}$ Међутим, за разлику од Атине, где су се аристократски родови у архајској епоси борили за престиж и преко херојских имена и херојских генеалогија, не налазимо видљиве и јасне политичке разлоге за давање имена Пејсистрат као личног имена код Рођана. Да је ово име код острвљана постало временом у тој мери „обично“, нека покаже само један пример из Линда на Родосу, где је још током IV века пре н. е. забележен грађанин Пејсистрат

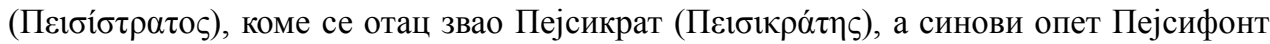

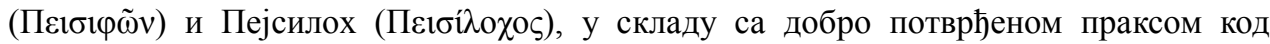
Хелена да се карактеристичан и препознатљив елемент имена Пєьбь- задржава кроз генерације у породичној антропонимији. ${ }^{33}$ Наведени Пејсифонт, син истог

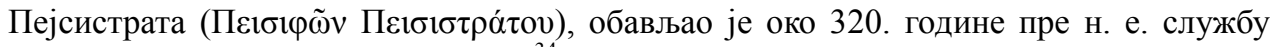
свештеника богиње Атене Линдије. ${ }^{34}$

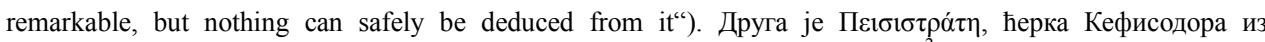
приморске деме Арафен, потврђена такође на надгробном споменику ( $\left.I G \mathrm{II}^{2} 5696\right)$ из прве половине IV века пре н. е. Упор. $L G P N$ II, s. v. Peisistratê (1)-(2).

${ }_{28} I G \mathrm{II}^{2} 2208$ II, ред 130 (датовање 211/212. год. н. е.). Упор. $L G P N$ II, s. v. Peisistratos (7).

${ }^{29}$ Упор. LGPN I, s. v. Peisistratos (19)-(62).

${ }^{30}$ Вид. нпр. R. Münsterberg, Die Beamtennamen auf den griechischen Münzen, repr. Hildesheim, Zürich - New York 1985, 127.

31 Само за потврде имена на сасвим „новим“ налазима рођанских амфора током последњих десетак година, упор. нпр. SEG 51, 902C (Солун); SEG 52, 564 (Тесалија); SEG 52, 1497 (Пафос, Кипар). За хронологију епонимних свештеника бога Хелија који су забележени на амфорама, упор. G. Finkielsztejn, Chronologie détaillée et révisée des éponymes amphoriques rhodiens, de 270 à 108 av. J.-C. environ. Premier bilan (BAR International Series 990), Oxford 2001; C. Habicht, Rhodian Amphora Stamps and Rhodian Eponyms, Revue des études anciennes 105, Bordeaux 2003, 541-587.

${ }_{32}$ Упор. М. Обрадовић, Прилози проучавању нелеидске антропонимије II: херојско име Трасимед као лично име код Хелена, Истраживања 24, Нови Сад 2013, 32-34.

${ }^{33}$ I. Lindos 51a I, редови 49-50 (датовање између 325. и 320. године пре н. е.); I. Lindos 53. Упор. LGPN I, s. v. Peisistratos (62).

${ }^{34}$ I. Lindos 53. 
Од градова старе дорске пентеполе име Пејсистрат је као лично име потврђено и у Книду на новцу града. ${ }^{35}$ И на богатом острву Косу, славном по култу бога Асклепија, такође је више грађана носило лично име Пејсистрат у хеленистичком раздобљу. ${ }^{36}$ По сличном обрасцу као у горе наведеном случају породице из Линда на Родосу, грађанин Коса који је носио име Пејсистрат

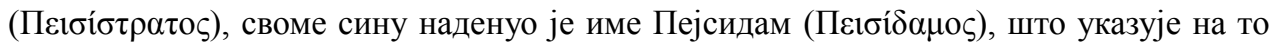
да су се имена овог типа наслеђивала у тој породици кроз више генерација. ${ }^{37}$ Недавно је Пејсистратово име прочитано и као име епонимног магистрата (монарха) града Коса на важном натпису с почетка III века пре н. е. којим су регулисана правила у вези са избором свештеника (вероватно Асклепијевог култа?). ${ }^{38}$ Име

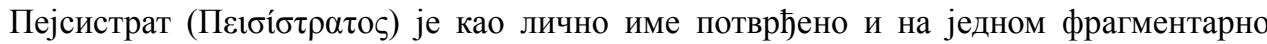
сачуваном натпису из око 240. године пре н. е., који бележи дугу, по алфабетском реду сређену листу грађана, даваоца доприноса за одређену намену. ${ }^{39}$ На оближњем је дорском острву Калимносу име Пејсистрат, опет, чак два пута потврђено као лично име на једном истом натпису с краја III века пре н. е. ${ }^{40}$ Исто тако, на малом дорском острву Нисиру је, можда под утицајима који су стизали са оближњег Родоса, такође већ крајем IV или почетком III века пре н. е. потврђено име Пејсистрат као лично име, где се тако звао отац извесног Фаина (Фаі̃vсs

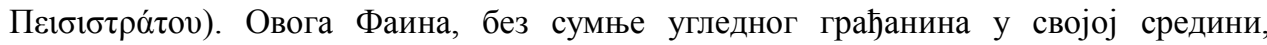
грађани Делоса су начинили својим проксеном за услуге које је учинио у вези са Аполоновим храмом на Делосу у првој половини III века пре н. е. ${ }^{41}$ Сви овде наведени примери са доминантно дорских острва и градова из малоазијске Дориде (Родос, Кос, Книд, Калимнос) могли би најпре да укажу на панхеленски карактер Пејсистратовог имена, што је нашло одраз у антропонимији ове, али видећемо такође, и других области грчког света, а нарочито у хеленистичкој епоси.

Карактеристични примери коришћења херојског имена Пејсистрат као антропонима забележени су и у другим дорским градовима широм Медитерана. На Липари, највећем од свих Еолских острва на западу близу обале Сицилије, где је још у првој половини VI века пре н. е. образована дорска колонија пореклом из малоазијског Книда, име Пејсистрат се као лично име јавља вероватно у IV веку пре н. е. и то као име једног историчара. Тако се, наиме, звао локални историограф о коме данас не знамо готово ништа, осим да га је користио и цитирао Тимеј, најпознатији писац историје западних Грка. ${ }^{42}$ На сасвим другој страни на јужним обалама Црног мора херојско име Пејсистрат је као лично име било популарно и у дорској Хераклеји Понтици, где је, такође у IV веку, потврђено као име градског

\footnotetext{
${ }^{35}$ R. Münsterberg, Op. cit., 117.

${ }^{36} L G P N$ I, s.v. Peisistratos (13)-(15).

${ }^{37} I G$ XII 4, 1, 75A, ред 153 (датовање 202/201. година пре н. е.). Упор. LGPN I, s. v. Peisistratos (14).

${ }^{38} S E G 51,1054$ В, редови 2 и $10=I G \mathrm{XII} 4,1,296$ (датовање између 295. и 280. године пре н. е.).

${ }^{39} S E G$ 48, 1098 А90 = IG XII 4, 1, 70, ред 90.

${ }^{40}$ Tit. Cal. 85, редови 6 и 51. Упор. LGPN I, s. v. Peisistratos (11)-(12).

${ }^{41} I G$ XI 4, 595. Упор. $L G P N$ I, s. v. Peisistratos (17).

${ }^{42}$ W. Kroll, RE 19, 1938, 191-192, s. v. Peisistratos (7); FGrHist 574 [Pisistratus Liparaeus]; LGPN IIIA, s. v. Peisistratos (4).
} 
магистрата на локалним амфорама, ${ }^{43}$ а недалеко одатле у јонском Амисосу (колонија Фокеје или Милета) већ у првој половини IV века пре н. е. као име магистрата на новцу града. ${ }^{44}$ Није лако наслутити разлоге за оваква именовања. Може се само нагађати да је име дато са свешћу да је историјско или ратничко или, опет, да се јавља као део породичне традиције и да је могло бити наслеђивано кроз генерације. Такав нејасан случај забележен је и у ајолском граду Ену у Тракији код ушћа Хебра,

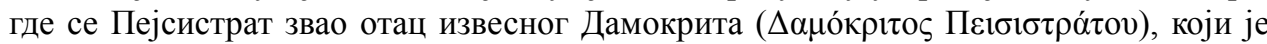
360/359. или 316. године пре н. е. обављао службу теародока светковине у Епидауру на Пелопонезу у част бога Асклепија. ${ }^{45}$

Неке потврде антропонима Пејсистрат у грчком свету заслужују, међутим, далеко већу пажњу. То би, пре свега, због митова и традиције о заједничкој јонској и нелеидској прошлости, могло да се односи на градове малоазијске Јоније. Чињеница

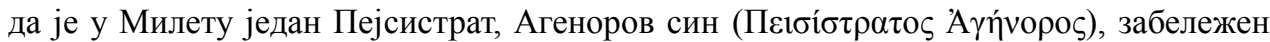
као епонимни магистрат, стефанефор града средином V века пре н. е., ${ }^{46}$ ако се посматра у контексту других савремених извора и у једном сложеном политичком тренутку у коме се град Милет налазио, отвара многе комбинације и могућности за различита тумачења. Доводећи у везу податке из различитих, пре свега, документарних извора - милетска листа епонимних стефанефора (Milet I 3, 122), атински декрет који се тицао Милета из можда 450/449. године пре н. е. $\left(I G \mathrm{I}^{3} 21\right)$, милетски декрет који предвиђа протеривање из града припадника појединих аристократских породица (Milet I 6, 187 = Meiggs/Lewis, GHI 43), савезничке квоте у најстаријим списковима фороса Атинског поморског савеза, почевши од 454/3. године пре н. е. (IG $\mathrm{I}^{3}$ 259ff.) - поједини научници су претпоставили постојање олигархијске владе у Милету средином V века пре н. е. у којој су водећу улогу имали представници старог „нелеидског“ племства, заправо породице које су изводиле своје порекло од Нелеја, оснивача јонског Милета. ${ }^{47}$ Ову олигархијску владу је, у складу са наведеном претпоставком, демократска Атина у почетку подржавала или бар толерисала, изгледа управо из разлога да се преко „нелеидских“ веза истакне и оснажи положај Атине као метрополе свих Јоњана. Касније су се, међутим, Милећани побунили ${ }^{48}$ и за известан број година отпали из Савеза. Ова

\footnotetext{
${ }^{43}$ Упор. I. Heraclea, p. 156; LGPN VA, s. v. Peisistratos (16).

${ }^{44}$ Упор. $L G P N$ VA, s. v. Peisistratos (15).

${ }^{45} I G$ IV $1^{2} 94 \mathrm{~b}$, редови 48-49. Упор. LGPN IV, s. v. Peisistratos (5).

${ }^{46}$ Milet I 3, 122 I, ред 81 (епонимни стефанефор за 446/5. годину пре н. е.).

${ }^{47}$ О политичкој ситуацији у Милету у светлу наведених докумената (нарочито на основу поменуте одлуке о протеривању аристократа, Milet I 6, 187), као и о природи атинско-милетских односа током V века пре н. е., литература је обимна и разноврсна: G. Glotz, Une inscription de Milet, Comptes rendus des séances de l'Academie des Inscriptions et Belles-Lettres, 1906, 8, Paris 1906, 511-529; A. J. Earp, Athens and Miletus c. 450 B. C., Phoenix 8, Toronto 1954, 142-147; J. P. Barron, Milesian Politics and Athenian Propaganda, Journal of Hellenic Studies 82, London 1962, 1-6; Meiggs/Lewis, GHI, 105-107, No. 43; P. Herrmann, Zu den Beziehungen zwischen Athen und Milet in 5. Jahrhundert, Klio 52, Berlin 1970, 163-173; R. Meiggs, Athenian Empire, Oxford 1972, 562-565; H.-J. Gehrke, Zur Geschichte Milets in der Mitte des 5. Jahrhunderts v.Chr. Historia 29, Wiesbaden 1980, 17-31; N. Robertson, Government and Society at Miletus, 525-442 B. C., Phoenix 41, Toronto 1987, 356-398; P. J. Rhodes, The Delian League to 449 B. C., The Cambridge Ancient History $\mathrm{V}^{2}$ (edd. D. M. Lewis, J. Boardman, J. K. Davies, M. Ostwald), Cambridge 1992, 58-59; B. Gorman, Miletos, the Ornament of Ionia: A History of the City to 400 B. C. E., Ann Arbor 2001, 216-236.

48 Једну побуну милетских олигараха, које су најпре Атињани подржали, а ови искористили прилику да
} 
претпостављена политичка превирања и преврати у Милету средином V века пре н. е. можда су оставили траг и у фрагментарно сачуваним списковима фороса, доприноса савезника, где се милетска квота, која је 449. године пре н. е. износила 10 таланата, уопште не бележи у постојећим фрагментима за период између 446/5. и 444/3. године $\left(I G \mathrm{I}^{3} 266-268\right)$, а поново се јавља тек 443/2. године пре н. е. (IG $\mathrm{I}^{3}$ 269), сада у преполовљеном износу од 5 таланата, када је, како се сматра, коначно оборена олигархијска влада и донета поменута одлука о протеривању њених првака (Milet I 6, 187). У једној таквој реконструкцији догађаја име Пејсистрата, милетског епонимног стефанефора за 446/5. годину, када је, како изгледа, олигархијска управа била на врхунцу, може да побуди „нелеидске“ асоцијације и комбинације. Није,

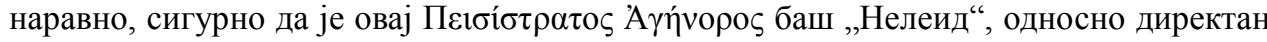
потомак старог милетског племства које је изводило порекло од хероја Нелеја, митског оснивача Милета, односно од Нелеида из Пила. ${ }^{49}$ Такође није сигурно ни датовање неких од наведених докумената, а нарочито је у том погледу спорна одлука атинске скупштине која предвиђа директну атинску интервенцију у Милету $\left(I G \mathrm{I}^{3}\right.$ 21). ${ }^{50}$ Међутим, осим имена овог Пејсистрата, као и његовог патронимика, још неке индиције, које се често занемарују, као да иду у прилог једном таквом тумачењу.

Важно је најпре истаћи да је име Пејсистрат ипак ретко забележено као антропоним у старим градским центрима Јоније. Ово је, колико нам је познато, и јединствен случај личног имена Пејсистрат када је реч о самом Милету, што је прилично необично за град дуге и богате традиције, чијих је више хиљада грађана забележено по имену у различитим изворима. ${ }^{51}$ То, наравно, не важи и за милетске колоније, како то, на пример, показује Пејсистрат из града Кизика на Пропонтиди из епохе римских ратова са Митридатом VI Еупатором. Овога Пејсистрата бележи историчар Апијан као одлучног стратега у одбрани града у време када је понтски краљ Митридат опседао Кизик. ${ }^{52}$ Међутим, ни у осталим градовима Јоније херојско име Пејсистрат није чест антропоним. У Ефесу, на пример, у коме је, од свих јонских градова уопште, у изворима забележено далеко највише антропонима, бележимо први поуздани случај личног имена Пејсистрат тек у II веку пре н. е., на натпису који садржи списак лица, вероватно грађана, чиновника или ефеба (?)

направе покољ у народу, потврђује псеудо-Ксенофонтов Атински устав ([Xen.] Ath. Pol. III 11), али овај конкретни случај побуне тешко је прецизније датовати, као, уосталом, и цео спис Атински устав. Упор. нпр. H. В. Mattingly, The Date and Purpose of the Pseudo-Xenophon, Classical Quarterly 47, London 1997, 352-357.

${ }^{49}$ Како то за извесно држи, на пример, J. Р. Barron, Milesian Politics and Athenian Propaganda, 4.

${ }^{50}$ Упор. H. В. Mattingly, The Athenian Decree for Miletos $\left(I G I^{2}, 22+=\right.$ ATL II, D 11): A Postscript, Historia 30, Wiesbaden 1981, 113-117. Овај, као и неке друге важне атинске документе, за које се раније претпостављало да потичу из средине V века пре н. е., Mattingly је аргументовано и са великим степеном вероватноће датовао у време Пелопонеског рата. Вид. Исти, The Athenian Empire Restored: Epigraphic and Historical Studies, Ann Arbor 1996.

${ }^{51}$ Нови том оксфордског Лексикона грчких личних имена, којим је обухваћена и територија града Милета, управо је изашао из штампе (J.-S. Balzat, R. W. V. Catling, E. Chiricat, F. Marchand (edd.), A Lexicon of Greek Personal Names V B: Coastal Asia Minor: Caria to Cilicia, Oxford 2014), тако да нисам успео да га консултујем до закључења овог рада.

${ }^{52}$ App., Mithr. 73 (датовање 74. год. пре н. е.). Упор. $L G P N$ VA, s. v. Peisistratos (13). 
града. ${ }^{53}$ Други познати случај могао би такође бити тек из хеленистичког периода и односи се на лице које се код Диогена Лаертија наводи као коментатор тзв.

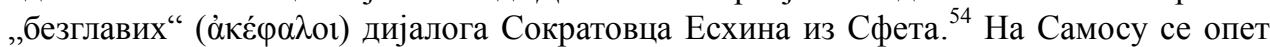
име Пејсистрат јавља раније (крај IV века пре н. е.), као име магистрата на новцу. ${ }^{55}$ Једино је име Пејсистрат као лично име заступљеније на јонском острву Хију, али најранији забележени случај није ипак старији од III века пре н. е. ${ }^{56}$ Извесно је, међутим, да је у једној угледној породици са острва Хија име Пејсистрат као лично име преношено кроз генерације са деде на унука, како би се то дало закључити на основу декрета Делоса из средине III века пре н. е. у част „Пејсистрата, сина Аргеја,

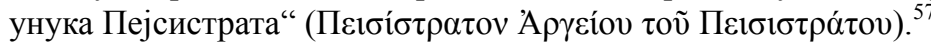

Ако се сада, међутим, вратимо Пејсистрату, Агеноровом сину, епонимном милетском стефанефору за 446/5. годину пре н. е., не можемо се отети утиску да је име и његовог оца такође веома интересантно. Агенор (А $\gamma \eta \dot{\eta} v \omega \rho)$ је добро херојско име, а грчки митови бележе бар десетак различитих личности са овим именом. Од свих ових Агенора посведочених у богатој грчкој традицији, најпознатији је свакако Агенор, отац великог хероја Кадма, оснивача беотске Тебе/Кадмеје. Иако обележен у традицији као „странац“, владар Феничана, као Посејдонов син и родоначелник славног потомства (Еуропа, Феник, Киликс, и пре свих осталих, Кадмо), овај Агенор је најпре могао послужити као узор приликом давања личних имена, много пре него, на пример, Агенор, син Фегеја, убица Алкмеонов, или Антенорид Агенор, храбри Тројанац који није устукнуо ни пред махнитим Ахилејем, а на крају га је убио Неоптолем. $^{58}$ у прилог овом мишљењу може се навести и само значење имена

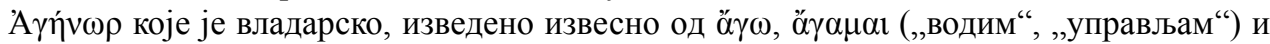
$\dot{\alpha} v \eta ́ \rho$, у сложеницама већ карактеристично код Хомера $-\eta \nu \omega \rho /-\alpha \nu \omega \rho,{ }^{59}$ и као такво пристаје припаднику угледног рода који своје порекло изводи од херојских

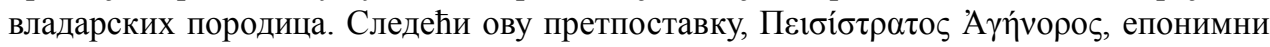
магистрат града Милета за 446/5. годину пре н. е., представник је породице, или можда боље речено, браковима повезаних породица, које су у генеалошкој сфери „баштиниле“ порекло од хероја Нелеја и Кадма. А управо „нелеидске“ и „кадмејске“ везе и генеалогије су и карактеристичне за угледне Милећане архајске епохе. Тако је, на пример, породица славног мудраца Талеса (VII-VI век пре н. е.) изводила феничко, читај „кадмејско“, порекло, а један од, у традицији, најстаријих милетских и уопште грчких прозних писаца и историчара (крај VI века) носио је, сигурно не

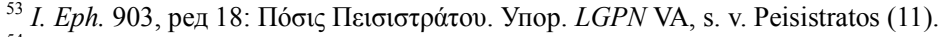

${ }^{54}$ Diog. Laert. II 60. Упор. W. Kroll, $R E$ 19, 1938, 191, s. v. Peisistratos (6); $L G P N$ VA, s. v. Peisistratos (10).

${ }^{55}$ R. Münsterberg, Op. cit., 111; J. P. Barron, The Silver Coins of Samos, Oxford 1966, 214-216. Упор. LGPN I, s. v. Peisistratos (63).

${ }_{56}^{5}$ Упр. $L G P N$ I, s. v. Peisistratos (1)-(5).

${ }^{57} I G$ XI 4, 598, redovi 9-10. LGPN I, s. v. Peisistratos (1)-(2).

58 Занимљиво је да, на пример, J. Р. Barron, Milesian Politics and Athenian Propaganda, 4, доводећи у везу лично име Агенор у Милету са овим митским Агенором, Антеноровим сином, наводи чак да је име Агенор „тројанско“!

${ }_{59}$ Упор. Н. von Kamptz, Homerische Personennamen: sprachwissenschaftliche und historische Klassifikation, Göttingen 1982, 97, 177.
} 
случајно, лично име Кадмо $($ Ка́ $\delta \mu \varsigma) .{ }^{60}$ У сваком случају, име и патронимик поменутог епонимног стефанефора Милета за 446/5. годину пре н. е., могу да послуже и као додатно сведочанство у реконструкцији политичке историје града средином V века пре н. е., у периоду у коме је, како се у науци претпоставља, привремено успостављена олигархијска влада у Милету. И нека друга имена епонимних магистрата на наведеној листи милетских стефанефора, као, на пример,

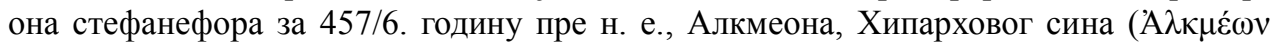

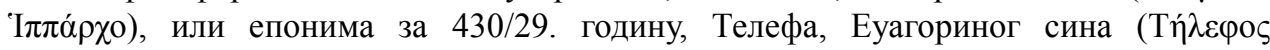
Еỏ $\gamma o ́ \rho \varepsilon()$, могли би да укажу на привремену доминацију аристократских родова, који су, у борби за престиж и утицај, своје порекло изводили од хероја, а да би подсетили савременике на своје славне претке, давали и херојска имена потомству. ${ }^{61}$

Као у Милету, тако је и на богатом јонском острву Тасосу име Пејсистрат могло, нарочито у архајском и класичном периоду, да изгледа и „звучи“ аристократски. Овде се име Пејсистрат као антропоним јавља доста рано у списковима теора још током VI века пре н. е., када су, сасвим извесно, ови чиновници и бирани искључиво из редова аристократије и угледника. ${ }^{62}$ Од других

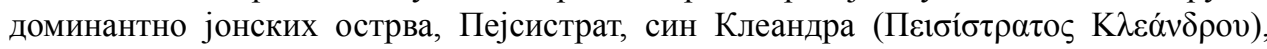
забележен је на натпису из града Еретрије на Еубеји на прелазу из IV у III век пре н. е. ${ }^{63}$ Из средине III века је, опет, Пејсистрат са острва Пароса у Кикладима. ${ }^{64}$ Од јонских је кикладских острва име Пејсистрат потврђено као лично име и на Делосу у првим деценијама II века пре н. е. ${ }^{65}$ С друге стране, на острву Теносу у Кикладима

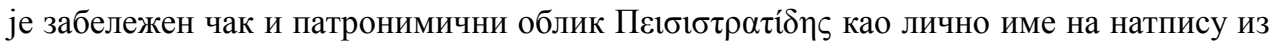
прве половине III века пре н. е. ${ }^{66}$ Патронимични облик може да укаже најпре да се деда по оцу, или неки други ближи предак, овог Пејсистратида звао Пејсистрат

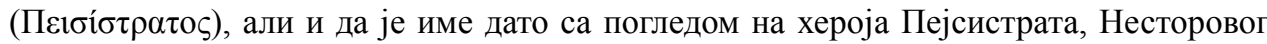
сина. Уколико је ова друга претпоставка ближа истини и нека породица на острву заиста изводила и порекло од хероја Пејсистрата, вероватно је реч о локалној традицији коју је данас тешко пратити, али је свакако занимљиво истаћи и да се отац

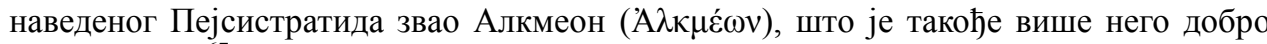
херојско име. ${ }^{67}$

У Орхомену, старом граду богате традиције у Беотији, Пејсистрат

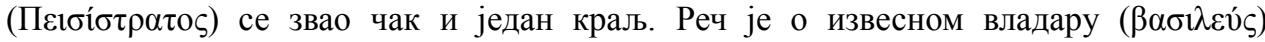

\footnotetext{
${ }^{60}$ Упор. M. Obradović, Notes on the Name Kadmos as a Personal Name in the Greek-speaking World, Зборник Филозофског факултета у Београду, Серија А: Историјске науке, књига XX, Београд 2006, Sobria ebrietas: У спомен на Мирона Флашара, 194-195, за ове и друге „Кадмејце“ и „Нелеиде“ у Милету.

${ }^{61}$ Milet I 3, 122 I, редови 70 и 97. За разлоге зашто се име Телеф, које опет припада „хераклидском“ репертоару херојских грчких имена, јавља као антропоним, упор. М. Obradović, Herojsko ime Telef kao lično ime kod Helena, Зборник Матице српске за класичне студије 9, Нови Сад 2007, 73-89.

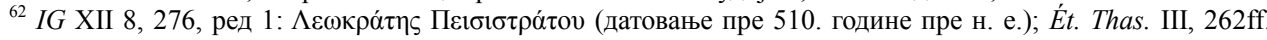

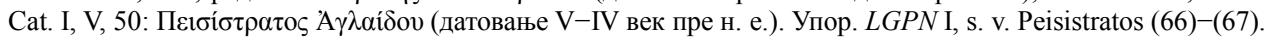

${ }^{63} I G$ XII 9, 730. Упор. $L G P N$ I, s. v. Peisistratos (10).

${ }^{64} I G$ XII 5, 445, ред 46. Упор. LGPN I, s. v. Peisistratos (18).

${ }^{65}$ I. Délos 442 В, ред 250 (датовање 179. год. пре н. е.). Упор. LGPN I, s. v. Peisistratos (9).

${ }^{66} I G$ XII 5, 872, ред 43.

${ }^{67}$ За породицу овог Алкмеона, вид. R. Etienne, Ténos II. Ténos et les Cyclades du milieu du IV siècle av. J.-C. au III siècle ap. J.-C., Paris 1990, 75.
} 
Орхомена из времена Пелопонеског рата, против кога су припадници аристократије сковали заверу јер је нагињао демосу, а коме је чак и рођени син Тлесимах

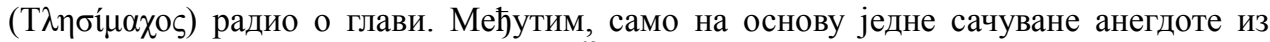
псеудо-Плутархових Parallela minora, ${ }^{68}$ тешко да се може нешто више закључити о веродостојности целог случаја или о разлозима за ово именовање. Али, како је у причи очигледно реч о краљу (или можда о магистрату са титулом $\beta \alpha \sigma \iota \lambda \varepsilon v ́ \varsigma)$, не треба искључити могућност да је име програмско, дато управо са погледом на хероја Пејсистрата, пре него на неког историјског Пејсистрата. Орхомен је, уосталом, град богате историје и традиције, значајним делом независне од осталих беотских центара, а која је већ у хомерском Каталогу бродова у Илијади изражена кроз постојање засебног контингента Аспледона и „минијског“ Орхомена на челу са херојима Аскалафом и Јалменом. ${ }^{69}$ Владарска породица Орхомена историјских епоха могла је следити ове епске обрасце, али исто тако изводити „сродство“ и са другим херојским краљевским кућама. О минијско-нелеидским везама сведоче бројни трагови у хеленском миту и традицији. ${ }^{70}$ Могло је да се, у том контексту, у оквиру водеће породице у Орхомену и јави име Пејсистрат као лично име. Проблем је, међутим, то што, на основу преосталих сачуваних извора, не знамо за постојање краљева Орхомена у класичном периоду, а у времену у коме је наводно реч у наведеном случају (друга половина V пре н. е. у време Пелопонеског рата), уређење Орхомена у Беотији је извесно олигархијско са Већем у које су имали приступа само имућни грађани. ${ }^{71}$ Вероватно је зато у случају наведеног краља Пејсистрата реч о једној локалној традицији, која је могла била позната још Плутарху, односно кругу људи око њега, због близине и заједничке прошлости Орхомена и Херонеје. ${ }^{72}$

Из Беотије је и тебански државник Пејсистрат из хеленистичке епохе (III-II век пре н. е.). Он је у време Другог македонског рата (200-197. год.) важио за једног од вођа проримске странке у Теби и био одговоран, како извештава Полибије, за смрт истакнутог војсковође и беотарха Брахила, најважнијег македонског савезника у Беотији. ${ }^{73}$ Када је већ реч о средњој Грчкој, већи број потврда имена Пејсистрат као личног имена потиче из Делфа, великог панхеленског Аполоновог светилишта, али уједно и засебног полиса, у хеленистичком периоду (IV-I век пре н. е.). ${ }^{74}$ Ове потврде би могле најпре да представљају додатно сведочанство о панхеленском карактеру које је име Пејсистрат имало, нарочито у епоси хеленизма, али и да укажу на локалну традицију о којој се данас може само нагађати. Проблем представља и то

\footnotetext{
${ }^{68}$ Plut. Mor. 313B-C = FHG IV 515-516, F2 (као извор цитиран мало познати историчар Теофил у II књизи своје Историје Пелопонеског рата). Упор. LGPN IIIB, s. v. Peisistratos (1).

${ }^{69}$ Il. II 511-516. За „минијски” контингент и географско-историјске податке у Каталогу, упор. E. Visser, Homers Katalog der Schiffe, Stuttgart-Leipzig 1997, 364-378.

${ }^{70}$ Упор. нпр. F. Kiechle, Pylos und der pylische Raum in der antiken Tradition, Historia 9, Wiesbaden 1960, $38-45$.

${ }^{71}$ Упор. Thuc. IV 76, 3; Diod. XV 79, 3; Hell. Oxy. 19, 2, 3.

72 Орхомен је у класичном периоду у свом саставу имао и територију Херонеје, а то је извесно било тако и 424. године пре н. е. за трајања Пелопонеског рата. Упор. Thuc. IV 76, 3.

${ }^{73}$ Polyb. XVIII 43, 5-6; Упор. P. Schoch, RE 19, 1938, 191, s. v. Peisistratos (5); LGPN IIIB, s. v. Peisistratos (2).

${ }^{74} L G P N$ IIIB, s. v. Peisistratos (3)-(30).
} 
што је за период до почетка III века пре н. е. забележен само мали број антропонима Делфљана, па нисмо увек сигурни да ли се ово, као и нека друга у документарним изворима потврђена занимљива лична имена, карактеристична за грађане Делфа, јављају као наслеђе прошлости, или као израз једне нове праксе у давању личних имена у хеленистичком периоду. ${ }^{75}$

За крај смо, свакако не случајно, оставили примере Пејсистратовог имена као антропонима у Спарти. Ови примери такође могу да сведоче да је име код Грка имало или временом стекло панхеленски карактер. Један Спартанац Пејсистрат

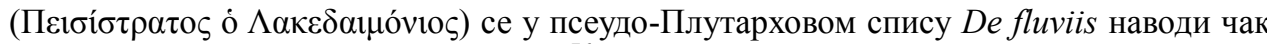
као оснивач града Норика у Фригији. ${ }^{76}$ Ако је овај пример историјски несигуран, то свакако већ није случај са Спартанцем Пејсистратом, чији је син крајем IV века пре н. е. потврђен као лакедемонски представник у Делфима. ${ }^{77}$ Још један Спартанац

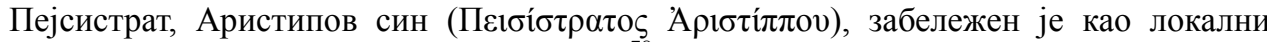
магистрат на споменику из I века пре н. е. ${ }^{78}$

Списак скраћеница епиграфских и лексикографских публикација:

Chantraine, $D E L G=\mathrm{P}$. Chantraine, Dictionnaire étymologique de la langue Grecque. Histoire des mots, I-IV, Paris 1968-1980.

Ét. Thas. III = J. Pouilloux, Recherches sur l'histoire et les cultes de Thasos I. De la foundation de la cité à 196 avant J.-C. (Études thasiennes III), Paris 1954.

FD III = Fouilles de Delphes III. Épigraphie, Paris 1909-1985.

FGrHist $=$ F. Jacoby, Die Fragmente der griechischen Historiker, Leipzig-Leiden 1923-1957. Erster Teil: Genealogie und Mythographie, Leipzig 1923, Leiden $1957^{2}$. Zweiter Teil: Zeitgeschichte (1926-1930). Dritter Teil: Geschichte von Städten und Völkern (1940-1954).

FHG IV = Fragmenta historicorum graecorum, vol. IV (ed. C. Müller), Paris 1851.

I. Délos = Inscriptions de Délos I-VII (edd. F. Durrbach, P. Roussel, M. Launey), Paris 1926-1972.

I. Eph. $=\mathrm{H}$. Wankel, R. Merkelbach et alii, Die Inschriften von Ephesos, I-VII (Inschriften griechischer Städte aus Kleinasien Band 11-17), Bonn 1979-1981.

$I G=$ Inscriptiones Graecae:

$I G \mathrm{I}^{3}=$ Inscriptiones Graecae I: Inscriptiones Atticae Euclidis anno anteriores. Berlin 1981-1994. Fasc. 1, ed. D. Lewis, Decreta et Tabulae Magistratuum (nn. 1-500); fasc. 2, ed. D. Lewis, L. Jeffery, Dedicationes. Catalogi. Termini. Tituli Sepulcrales. Varia. Tituli Attici Extra Atticam Reperti. Addenda (nn. 501-1517).

$I G \mathrm{II}^{2}=$ Inscriptiones Atticae Euclidis anno posteriores, I-III, ed. J. Kirchner, Berlin 1913-1940.

$I G \mathrm{IV}^{2} 1$ = Inscriptiones Graecae IV: Inscriptiones Argolidis. Fasc. 1, Inscriptiones Epidauri, ed. F. Hiller von Gaertringen. Berlin 1929.

\footnotetext{
75 Упор. Р. М. Fraser, Delphian Names, Bulletin de Correspondance Hellénique Suppl. 36, Athènes 2000, 141-147, за карактеристике ове „нове“ номенклатуре у Делфима.

${ }^{76}$ Ps. Plut. De fluv. 10, 2 = Plut. Mor. 1156В-С. Упор. Р. Poralla, Prosopographie der Lakedaimonier bis auf Zeit Alexanders des Großen, Breslau 1913, 105, Nr. 605. LGPN IIIA, s. v. Peisistratos (1).

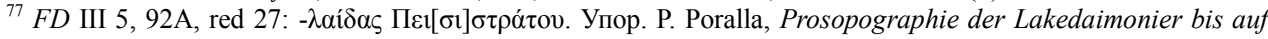
Zeit Alexanders des Großen, Breslau 1913, 105, Nr. 606; LGPN IIIA, s. v. Peisistratos (2).

${ }^{78} I G \mathrm{~V} 1,126$, редови 6-7. Упор. LGPN IIIA, s. v. Peisistratos (3).
} 
IG V 1 = Inscriptiones Graecae V: Inscriptiones Laconiae, Messeniae, Arcadiae. Fasc. 1, Inscriptiones Laconiae et Messeniae, ed. W. Kolbe, Berlin 1913.

IG XI 4 = Inscriptiones Graecae XI 4: Inscriptiones Deli (nn. 510-1349), ed. P. Roussel, Berlin 1914.

IG XII 4, 1 = Inscriptiones Graecae XII 4, 1: Inscriptiones Coi, Calymnae, insularum Milesarium. Pars. 1: Inscriptionum Coi insulae: Decreta, epistulae, edicta, tituli sacri, edd. D. Bosnakis, K. Hallof, K. Rigsby, Berlin 2010.

IG XII 5 = Inscriptiones Graecae XII,5. Inscriptiones Cycladum, ed. F. Hiller von Gaertringen, I-II, Berlin 1903-1909.

IG XII 8 = Inscriptiones Graecae XII,8. Inscriptiones insularum maris Thracici, ed. C. Friedrich, Berlin 1909.

IG XII 9 = Inscriptiones Graecae XII,9. Inscriptiones Euboeae insulae, ed. E. Ziebarth, Berlin 1915.

I. Heraclea $=$ L. Jonnes, Inscriptions of Heraclea Pontica (Inschriften griechischer Städte aus Kleinasien, Band 47), Bonn 1994.

I. Lindos = C. Blinkenberg, Lindos. Fouilles et recherches, II. Fouilles de l'acropole. Inscriptions, Berlin-Copenhagen 1941.

Jeffery, $L S A G=\mathrm{L}$. H. Jefery, The Local Scripts of Archaic Greece, Oxford 1961.

$L G P N=A$ Lexicon of Greek Personal Names:

$L G P N$ I = P. M. Fraser, E. Matthews (edd.), A Lexicon of Greek Personal Names I: The Aegean Islands, Cyprus and Cyrenaica, Oxford 1987.

$L G P N$ II = M. G. Osborne, S. G. Burne (edd.), A Lexicon of Greek Personal Names II: Attica, Oxford 1994.

$L G P N$ III A = P. M. Fraser, E. Matthews (edd.), A Lexicon of Greek Personal Names IIIA: The Peloponnese, Western Greece, Sicily and Magna Graecia, Oxford 1997.

$L G P N$ III B = P. M. Fraser, E. Matthews (edd.), A Lexicon of Greek Personal Names IIIB: Central Greece: From the Megarid to Thessaly, Oxford 2000.

$L G P N$ IV = P. M. Fraser, E. Matthews (edd.), A Lexicon of Greek Personal Names IV: Macedonia, Thrace, Northern Regions of the Black Sea, Oxford 2005.

$L G P N$ V A = Th. Corsten, R.W.V. Catling, M. Ricl (edd.), A Lexicon of Greek Personal Names V A: Coastal Asia Minor: Pontos to Ionia, Oxford 2010.

Milet $=$ Milet. Ergebnisse der Ausgrabungen und Untersuchungen seit dem Jahre 1899 (edd. Th. Wiegand et al.), Berlin 1906-2006:

Milet I 3 = G. Kawerau, A. Rehm, Das Delphinion in Milet, Berlin 1914.

Milet I 6 = A. von Gerkan, Der Nordmarkt und der Hafen an der Loewenbucht, Berlin 1922.

Meiggs/Lewis, GHI = R. Meiggs, D. Lewis, A Selection of Greek Historical Inscriptions, Oxford 1969.

$R E=$ Pauly-Wissowa (edd.), Real-Encyclopädie der classischen Altertumswissenschaft, Stuttgart 1893-1980.

SEG $=$ Supplementum Epigraphicum Graecum, Leiden-Amsterdam 1923- .

Tit. Cal. $=$ M. Segre, Tituli Calymnii, Annuario della Scuola Archeologica di Atene e delle Missione Italiane in Oriente XXII-XXIII (Nuova Serie VI-VII), 1944-1945.

\section{Литература:}

Andrews, A., The Greek Tyrants, London 1956.

Andrews, A., The Tyranny of Pisistratus, The Cambridge Ancient History III ${ }^{2} 3$ (edd. J. Boardman, N. G. L. Hammond), Cambridge 1982, 392-416.

Barron, J. P., Milesian Politics and Athenian Propaganda, Journal of Hellenic Studies 82, London 
1962, 1-6.

Barron, J. P., The Silver Coins of Samos, Oxford 1966.

Bechtel, F., Die historischen Personennamen des Griechischen bis zur Keiserzeit, Halle 1917.

Berve, H., Die Tyrannis bei den Griechen, I-II, München 1967.

Curty, O., Les parentés légendaires entre cités grecques. Catalogue raisonné des inscriptions

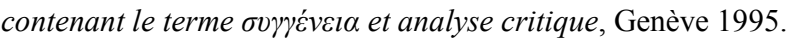

Davies, J. K., Athenian Propertied Families 600-300 B. C., Oxford 1971.

Develin, R., Athenian Officials 684-321 B. C., Cambridge 1989.

Earp, A. J., Athens and Miletus c. 450 B. C., Phoenix 8, Toronto 1954, 142-147.

Etienne, R., Ténos II. Ténos et les Cyclades du milieu du IV siècle av. J.-C. au III siècle ap. J.-C., Paris 1990.

Finkielsztejn, G., Chronologie détaillée et révisée des éponymes amphoriques rhodiens, de 270 à 108 av. J.-C. environ. Premier bilan (BAR International Series 990), Oxford 2001.

Fraser, P. M., Delphian Names, Bulletin de Correspondance Hellénique Suppl. 36, Athènes 2000, 141-147.

Gehrke, H.-J., Zur Geschichte Milets in der Mitte des 5. Jahrhunderts v.Chr., Historia 29, Wiesbaden 1980, 17-31.

Glotz, G., Une inscription de Milet, Comptes rendus des séances de l'Academie des Inscriptions et Belles-Lettres 1906, 8, Paris 1906, 511-529.

Gorman, B., Miletos, the Ornament of Ionia: A History of the City to 400 B.C.E., Ann Arbor 2001.

Habicht, C., Rhodian Amphora Stamps and Rhodian Eponyms, Revue des études anciennes 105, Bordeaux 2003, 541-587.

Herrmann, P., Zu den Beziehungen zwischen Athen und Milet in 5. Jahrhundert, Klio 52, Berlin 1970, 163-173.

Heubeck, A., West, S., Hainsworth, J. B., A Commentary on Homer's Odyssey, Vol. 1: Introduction and Books 1-8, Oxford 1988.

Jones, C. P., Kinship Diplomacy in the Ancient World, Cambridge, Mass. 1999.

Kamptz, H. von, Homerische Personennamen: sprachwissenschaftliche und historische Klassifikation, Göttingen 1982.

Kiechle, F., Pylos und der pylische Raum in der antiken Tradition, Historia 9, Wiesbaden 1960, $1-67$.

Lavelle, B. M., Fame, Money, and Power: The Rise of Peisistratos and "Democratic" Tyranny at Athens, Ann Arbor 2005.

Lücke, S., Syngeneia: Epigraphisch-historische Studien zu einem Phänomen der antiken griechischen Diplomatie (Frankfurter althistorische Beiträge, Bd. 5), Frankfurt am Mein 2000.

Mattingly, H. B., The Athenian Decree for Miletos (IG II ${ }^{2}, 22+=$ ATL II, D 11): A Postscript, Historia 30, Wiesbaden 1981, 113-117.

Mattingly, H. B., The Athenian Empire Restored: Epigraphic and Historical Studies, Ann Arbor 1996.

Mattingly, H. B., The Date and Purpose of the Pseudo-Xenophon, Classical Quarterly 47, London 1997, 352-357.

Meiggs, R., Athenian Empire, Oxford 1972.

Mühlestein, H., Nestors Enkel Peisistratos, Zeitschrift für Papyrologie und Epigraphik 87, Bonn 1991, 78.

Münsterberg, R., Die Beamtennamen auf den griechischen Münzen, repr. Hildesheim, Zürich - New York 1985.

Obradović, M., Notes on the Name Kadmos as a Personal Name in the Greek-speaking World, 
Зборник Филозофског факултета у Београду, Серија А: Историјске науке, књига XX, Београд 2006, Sobria ebrietas: У спомен на Мирона Флашара, 191-204.

Obradović, M., Herojsko ime Telef kao lično ime kod Helena, Зборник Матице српске за класичне студије 9, Нови Сад 2007, 73-89.

Обрадовић, М., Херојско име Антилох као лично име код Хелена, Истраживања 23, Нови Сад 2012, 95-109.

Обрадовић, М., Прилози проучаваъу нелеидске антропонимије II: херојско име Трасимед као лично име код Хелена, Истраживања 24, Нови Сад 2013, 23-39.

Poralla, P. Prosopographie der Lakedaimonier bis auf Zeit Alexanders des Großen, Breslau 1913.

Prinz, F., Gründungsmythen und Sagenchronologie (Zetemata 72), München 1979.

Rhodes, P. J., The Delian League to 449 B. C., The Cambridge Ancient History V² (edd. D. M. Lewis, J. Boardman, J. K. Davies, M. Ostwald), Cambridge 1992, 34-61.

Robertson, N., Government and Society at Miletus, 525-442 B. C., Phoenix 41, Toronto 1987, 356-398.

Sakellariou, M. B., La migration grecque en Ionie, Athènes 1958.

Thomas, R., Oral Tradition and Written Record in Classical Athens, Cambridge 1989.

Visser, E., Homers Katalog der Schiffe, Stuttgart-Leipzig 1997. 


\title{
STUDIES IN NELEID ANTHROPONYMY III: THE HEROIC NAME PEISISTRATOS AS A PERSONAL NAME AMONG THE GREEKS
}

\begin{abstract}
Summary

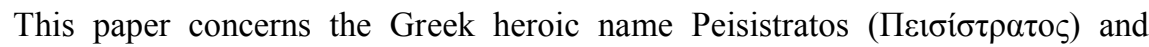
examines its distribution as a personal name in the ancient Greek world, from the Archaic to the Roman Imperial period. Possible reasons for choosing this heroic name for mortals have been discussed by analyzing available onomastic material from various parts of the Greek world. The geographical distribution of the name Peisistratos appears to be quite characteristic. Derived from the Greek peisi- and -stratos, the name by its meaning denotes the concept of the army and may appear as an appropriate name for a warrior. Nevertheless, the reasons for giving the heroic name Peisistratos to mortals should be sought primarily in the possible Neleid associations (Peisistratos was one of Nestor's sons) and in the fact that it is a good Homeric name well confirmed in the Odyssey. As such, it was acceptable especially to the Ionians, and consequently popular in Attica, and we may also note the significant concentration of the name elsewhere in the Ionian world, notably in Ionia proper and in the Aegean islands. It may be noted that several of these cases refer to eminent citizens. However, since the name Peisistratos was borne by the hero prominent in the Homeric epics, it could also be acceptable as a personal name not only to the Athenians and Ionians, but also to the other Greeks as a Panhellenic personal name. Although the hero Peisistratos in Homer does not belong to the rank of the great heroes, the name could sound to the Greeks like a good heroic and warrior name and desirable, like the other names from the heroic repertoire, in the choice of names given to children. In this light, it was unsurprisingly preferred by the Rhodians, with the notable presence in other neighbouring Dorian cities (Kos, Knidos, Kalymnos), from where a significant number of attestations dates from the Classical period onwards, but primarily from the Hellenistic period.

On the other hand, the paper discusses the reasons why the name Peisistratos as a personal name eventually became unwelcome in Athens itself. Since it was borne by the famous Athenian tyrant Peisistratos and members of his family, in Athenian democracy of $5^{\text {th }}$ and $4^{\text {th }}$ century BC, but also in later tradition, the name became unpopular and seen as tyrannical, and therefore could be considered a bad omen. It was not the case in other parts of the Greek world, and the name Peisistratos might have been given as a historical name, just after the famous Athenian Peisistratos.
\end{abstract}

Keywords: Peisistratos, Greek anthroponymy, myth, Greek epic tradition, history, politics, cultural values. 